\title{
What Factors Influence the Survival of Subsidised Start-ups for the Unemployed in Slovakia?
}

\author{
Peter Pisár \\ Matej Bel University in Banská Bystrica, Slovakia \\ peter.pisar@umb.sk \\ https://orcid.org/0000-0003-4898-2739 \\ Alexandra Mertinková \\ Matej Bel University in Banská Bystrica, Slovakia \\ alexandra.mertinkova@umb.sk \\ https://orcid.org/0000-0003-2235-3408 \\ Miroslav Šipikal \\ University of Economics in Bratislava, Slovakia \\ miroslav.sipikal@euba.sk \\ https://orcid.org/0000-0002-7205-3385
}

Received: 22. 10. 2021

Revised: 19.11.2021

Accepted: 29. 11. 2021

Published: 30.11. 2021

\section{ABSTRACT}

Purpose: The aim of the paper is to analyse the factors of sustainability of the public policy subsidising start-ups for the unemployed in Slovakia.

Design/Methodology/Approach: The analysis assesses the sustainability of subsidies in the period 2012-2016 based on data provided by the Ministry of Labour and Social Affairs. Logistic regression was used to identify the key factors.

Findings: Research shows that in times of economic growth, policies to support the self-employment of the unemployed are a particularly effective form of active labour market policy, especially in the more developed regions. On the contrary, when serving as a business support tool, they lead to very low survival rates of the subsidised companies compared to results of other studies. In terms of factors affecting this sustainability, the length of unemployment, the amount of support, as well as regional characteristics emerge as the most significant.

Practical implications: The results allow for a better definition of the conditions for providing subsidies to the unemployed to start a business in the future, while also showing that this instrument leads to employment retention rather than to the promotion of entrepreneurial activities. 
Originality/value: The research was carried out under specific conditions that had been little explored so far. The policy was evaluated at a time of strong economic growth accompanied by a significant reduction in unemployment. Also worth noting is that it was carried out in a country with some of the most pronounced regional disparities, which made it possible to compare the impact of the policy in different starting conditions.

Keywords: active employment policy, contribution to self-employment, subsidised start-ups for the unemployed

JEL: J48, H53, H5O

\section{Introduction}

Supporting entrepreneurship of the unemployed is one of the most frequently used public policy instruments. Its specificity lies in the fact that it seeks to address two problems at once. On the one hand, as an active labor market policy, it seeks to reduce unemployment and, on the other hand, as an economic policy, it seeks to promote the development of entrepreneurship, which is of particular importance, especially in less developed regions. This dual focus can have both advantages and disadvantages.

Subsidized start-ups from the state of unemployment in EU countries account for a very low share of total expenditure (less than 5\%). In the long term, the highest expenditure is recorded in Spain, which shows expenditure above 1\% of GDP. The most significant increase in spending is in Croatia, which in 2019 is closest to Spain. The most pronounced decline over the period 2012-2019 is visible in Slovenia, which is one of the lowest spending countries. Spending in the range of $0.04 \%$ of GDP - $0.06 \%$ of GDP is in countries such as Poland and France. All other countries are below $0.04 \%$ of GDP. Countries such as Ireland, Cyprus, Luxembourg, and Romania have zero spending on subsidized startups from the state of unemployment (Eurostat, 2021).

Although subsidized start-ups from the state of unemployment are low, they achieve significant positive effects (Bicentennial and Нога, 2020; Duhautois, Redor and Desiage, 2015; Caliendo and Kritikos, 2010; Baumgartner and Caliendo, 2008). Most studies examining the factors influencing the survival of this support focus on Western European countries (Germany: Niefert, 2010; Baumgartner and Caliendo, 2008, Caliendo and Künn, 2013; United Kingdom: Meager, Bates and Cowling, 2003; Finland: Haapanen and Tervo, 2009; France: Duhautois, Redor and Desiage, 2015; Spain: Millán and Congregado, 2010; Cueto, Mayor and Suárez, 2015).The aim of the paper is to fill some of these gaps and to analyze the survival rates as well as the sustainability factors of public policies aimed at self-employment as well as these rates of subsidized start-ups from the state of unemployment in Slovakia. We will look at this from the perspective of the sustainability of the employment of those who have benefited from it, as well as from the perspective of the sustainability of the supported entrepreneurial activities in the case of Slovakia. There are several reasons why Slovakia's analysis may be useful. 
Firstly, to focus on a country that has one of the lowest levels of funding in this area within the EU and is also not an economically strong country (GDP per capita is only $71 \%$ of the EU average). However, at the same time, it has achieved a very significant improvement in the unemployment rate over the period under review; in 2012 the unemployment rate was 14.4\%, while in 2017 it was only 5.94\%. Furthermore, the Slovak Republic is a country with very pronounced regional disparities, while regional characteristics are relatively rarely analyzed in similar studies (Caliendo et al., 2014). The government has identified the areas of the south and east of Slovakia (Prešov, Košice and Banská Bystrica regions) as the least developed regions, which we include in our analysis as an important element of the survival of self-employment. The last reason is the very long duration of the support (3 years), during which a person can quit the trade only under certain financial penalties. This represents a much longer period than similar supports examined in most other studies, e.g. in the case of Germany (Caliendo, 2016; Caliendo and Kritikos, 2010; Baumgartner and Caliendo, 2008; Caliendo and Kunn, 2013) it is one year and in the case of Finland (Haapanen and Tervo, 2009), it is financial support for 18 months.

The article consists of three parts. The first part is a literature review that reflects the current state of the issue of subsidized start-ups from the state of unemployment. The methodological part of the paper defines the specific instrument in Slovakia and the influencing factors. The results and conclusion bring together the findings on the Self-Employment Contribution in comparison with other studies and also identify opportunities for further research in this area.

\section{Literature review}

Supported business start-up from the state of unemployment includes measures to promote entrepreneurship by encouraging the unemployed and other target groups to start a business or become self-employed. Assistance may take the form of direct cash benefits or indirect support, including loans, provision of equipment, business advice, ... (LMP methodology 2018, 22).

Despite being one of the least subsidized instruments in EU countries, subsidized start-ups from the state of unemployment are very positive in several studies in terms of their effectiveness. For example, research in France (Duhautois, Redor and Desiage, 2015), suggests a positive impact on start-ups after the first two years compared to unsubsidized companies. A study from Germany (Caliendo and Kritikos, 2010) also shows a strong positive impact of the program on supporting start-ups. Baumgartner and Caliendo (2008) examined the impact of 2 self-employment programs and their results also show positive results after 22 months. Authors such as Dvouletý a Hora (2020) also positively evaluate subsidized start-ups from the state of unemployment.

However, the question remains what factors influence the survival rate of these start-ups. Another question is why the spending side of EU countries' employment policies does not invest more directly in this type of instrument. Potential factors affecting the of self-employment can be traced at different 
phases. The first of these is the stage of receiving support, which means that the individual is still only a candidate for benefit. Whether or not they receive the allowance is determined by the law and the structure of the conditions for receiving the allowance. There are also factors such as administrative complexity, or the time or complexity of meeting the conditions needed to obtain support. These factors are highly individual and more and more studies rely on behavioral aspects such as the motivation to start a business and the necessary preparation for it (Borik, 2012; Caliendo and Kritikos, 2010).

The second phase which can be observed during the support is a very risky phase, namely surviving the support. Here, too, we observe various influences that may make the successful implementation of the tool more difficult. Based on a review of factors in research published so far (Appendix 1) and country specifics, we monitor 3 categories of factors, namely:

1. Socio-demographic factors (gender, marital status, age, education, last and previous records held at the labor office, previous employment)

2. Regional labor market (work activity in an underdeveloped region, place of activity the same as the region in which the activity is carried out)

3. Economic factors (amount of aid, year of aid, economic cycle).

The importance of each factor varies from study to study. For example, the study Dvouletý, Hora (2020) included the length of registration at the labor office (analyzed in days) and the category of education as the main determinants of the location of tradesmen. By being a self-employed tradesperson from the state of unemployment, the amount of support to cover the lack of start-up capital when starting a business (especially in the short term) also plays an important role. In German studies (Caliendo and Kunn, 2013; Baumgartner and Caliendo, 2008), individual characteristics, human capital (represented by previous employment and education), but also the environment in which individuals operate have a major influence.

For most factors, the importance of individual factors in these studies varied, highlighting the need to examine them under different specific conditions. The individual results are discussed and confronted in more detail in the discussion section of this article.

\section{Methods}

The analysis covers the sustainability phase of support for unemployed people to start a business in the period 2012 - 2016 in the Slovak Republic. The datasets containing data for the Self-employment Allowance were created from data that were processed on the basis of 2 unique databases of the Ministry of Labor and Social Affairs on the supported subjects. This allows us to have sufficient data to track survival three years after the support.

The dataset for regression models up to 3 years consists of 6,950 observations, for models up to 6 months there are 9,997 observations. Post-support 
outcomes were monitored through 'follow-ups', with the database purged of missing and outlying data.

Specifically, the measure analyzed in the Self-employment Allowance is within the meaning of Section 49 of the Employment Services Act, which is an intensively used active policy instrument. The amount of support is granted within 30 days at $60 \%$ and then the remaining $40 \%$ of support for the past year. At the same time, the amount of support is conditional on the place of self-employment. In the case of the least developed regions (southern and eastern Slovakia), where districts have an average registered unemployment rate higher than the national average, the contribution is a maximum of 4 times the total labor cost calculated on the average wage of an employee. In the case of lower unemployment rates, it is 3 times, while in the Bratislava region (the region with the highest GDP per capita) it is only 2.5 times.

In our conditions, the support is only for job seekers who have been registered with the Labor, Social Affairs and Family Office for at least 3 months. The allowance is granted for partial reimbursement of costs related to the creation of a self-employment job and the subsequent operation of self-employment for at least three years.

We analyzed three research questions. First, in the case of Slovakia, there is a gap between the sustainability of the entrepreneurship of the supported persons and the sustainability of their employment in times of economic growth. The second question was whether different factors affect these types of sustainability differently. The third question was whether these factors differ in the short and long run after support.

The research methodology for the research question is based on 4 models that evaluate the sustainability of support based on 2 parameters as shown in Table 1. Different studies follow the factors at different time intervals (e.g. from up to 14 years (Haapanen and Tervo, 2009) and others for only 5 years (Caliendo and Künn 2013) or only two years (Niefert, 2010)). We decided to evaluate the sustainability of the support as short-term (up to 6 months after the end of the support) and long-term (up to 3 years), which could show us the differences in terms of time. The first 2 models evaluate sustainability from a broader perspective, where we take into account any survival of the supported subject in the labor market. The other 2 models are closely related to the self-employed cases only (so that the subjects remained in business). 
Table 1. Characteristics of models

\begin{tabular}{|c|c|c|}
\hline Model name & Dependent variable & Variable description and coding \\
\hline Model1_3overall & $\begin{array}{l}\text { sustainability of } \\
\text { supported person } \\
\text { on the labor market } \\
\text { after } 3 \text { years }\end{array}$ & $\begin{array}{l}3 \text { years after the end of the } \\
\text { support period, the supported } \\
\text { subject is employed as self- } \\
\text { employed, full-time employment } \\
\text { or by agreement = 1, otherwise = } \\
0 \text { (model1_3overall) }\end{array}$ \\
\hline Model2_6overall & $\begin{array}{l}\text { Sustainability of } \\
\text { supported person } \\
\text { on the labor market } \\
\text { after } 6 \text { months }\end{array}$ & $\begin{array}{l}6 \text { months after the end of the } \\
\text { support period, the supported } \\
\text { subject is employed as self- } \\
\text { employed, full-time employment } \\
\text { or by agreement = 1, otherwise = } \\
0 \text { (model2_6overall) }\end{array}$ \\
\hline Model3_3SZCO & $\begin{array}{l}\text { Business survival of } \\
\text { supported start-up } \\
\text { after } 3 \text { years }\end{array}$ & $\begin{array}{l}3 \text { years after the end of the } \\
\text { support period, the supported } \\
\text { subject is still running a } \\
\text { supported start-up self- } \\
\text { employed =1, otherwise =0 } \\
\text { (model3_3SzCO) }\end{array}$ \\
\hline Model4_6SZCO & $\begin{array}{l}\text { Business survival of } \\
\text { supported start-up } \\
\text { after } 6 \text { months }\end{array}$ & $\begin{array}{l}6 \text { months after the end of the } \\
\text { support period, the supported } \\
\text { subject is still running a } \\
\text { supported start-up = } 1 \text {, otherwise } \\
=0 \text { (model4_6SZCO) }\end{array}$ \\
\hline
\end{tabular}

Source: Author's own, 2021.

We use the logistic regression method (Wright, 1995) to evaluate the potential impacts, using the glm function (Generalized Linear Models) in the R program. as mentioned in the literature review.

For analyzing the determinants of survival of self-employment in Slovakia we use binary logit models with the form (Kaščáková a kol., 2010):

$\operatorname{logit}(\pi)=\ln \left(\frac{\pi}{1-\pi}\right)=\beta 0+\beta 1 \mathrm{X} 1+\ldots+\beta 11 \mathrm{X} 11$,

where $P\left(y_{i j}=1 \mid X\right)=\pi$ a $P\left(y_{i j}=0 \mid X\right)=1-\pi$ and $\left(\frac{\pi}{1-\pi}\right)=e^{\beta 0+\beta 1 X 1+\ldots+\beta 11 X 11}$.

Our models can be written:

$\mathrm{y}_{\mathrm{ij}}=f\left(\right.$ sodem $_{\mathrm{ij}}^{\prime}$; region $_{\mathrm{ijj}}^{\mathrm{ij}}$; eco $\left.{ }_{\mathrm{ij}}^{\prime}\right)+\varepsilon_{\mathrm{ij}}$,

where:

$$
\mathrm{y}_{\mathrm{ij}}\left\{\begin{array}{l}
\mathrm{y}_{\mathrm{i} 1}-\text { Model1_3overall } \\
\mathrm{y}_{\mathrm{i} 2}-\text { Model2_6overall } \\
\mathrm{y}_{\mathrm{i} 3}-\text { Model3_3SZCO } \\
\mathrm{y}_{\mathrm{i} 4}-\text { Model4_6SZCO }
\end{array}\right.
$$


What Factors Influence the Survival of Subsidised Start-ups for the Unemployed in Slovakia?

sodem $_{\mathrm{ij}}^{\prime}=\left(\mathrm{x}_{\mathrm{i} 1}, \mathrm{x}_{\mathrm{i} 2}, \mathrm{x}_{\mathrm{i} 3}, \mathrm{x}_{\mathrm{i} 4}, \mathrm{x}_{\mathrm{i} 5}, \mathrm{x}_{\mathrm{i} 6}, \mathrm{x}_{\mathrm{i} 7}\right)^{\prime}$,

region $_{\mathrm{ij}}^{\prime}=\left(\mathrm{x}_{\mathrm{i} 8}, \mathrm{x}_{\mathrm{i} 9}\right)^{\prime}$

$e^{e c o}{ }_{i j}^{\prime}=\left(x_{i 10}, x_{i 11}\right)^{\prime}$.

Now we can rewrite a system (1) corresponding to (2) into the following logistic models:

$\mathrm{f}_{1}\left(\mathrm{y}_{\mathrm{il}}\right)=\pi_{1} \mathrm{1}^{\mathrm{yil}}\left(1-\pi_{1}\right)^{\mathrm{yil}}$,

$\mathrm{f}_{2}\left(\mathrm{y}_{\mathrm{i} 2}\right)=\pi_{2}^{\mathrm{yi} 2}\left(1-\pi_{2}\right) \mathrm{yi}^{\mathrm{yi}}$,

$\mathrm{f}_{3}\left(\mathrm{y}_{\mathrm{i} 3}\right)=\pi_{3} \mathrm{y}^{\mathrm{ij}}\left(1-\pi_{3}\right)$
$\mathrm{f}_{1}\left(\mathrm{y}_{\mathrm{i}}\right)=\pi_{4}{ }^{\mathrm{ji}}\left(1-\pi_{4}\right)$

(4)

In each model 11 independent variables are analyzed as shown in Table 2 . The choice of selected variables reflects other studies 
Table 2. Description of the Independent variables that affect the probability of employment and self-employment

\begin{tabular}{|c|c|c|}
\hline \multirow[t]{6}{*}{$\begin{array}{c}\text { Model } \\
\text { specification }\end{array}$} & $\begin{array}{l}\text { Name of } \\
\text { variable }\end{array}$ & Variable description and coding \\
\hline & Gender $\left(x_{i 1}\right)$ & Gender of job seeker $($ male $=1$, female $=0)$ \\
\hline & Age $\left(x_{12}\right)$ & Age of the subject on the labor market in years. \\
\hline & $\begin{array}{l}\text { Marital status } \\
\qquad\left(\mathrm{x}_{\mathrm{i} 3}\right)\end{array}$ & $\begin{array}{l}\text { Marital status: if job seekers is not married }=1 \text {, otherwise } \\
=0\end{array}$ \\
\hline & $\begin{array}{l}\text { Length of last } \\
\text { record }\left(\mathrm{x}_{\mathrm{i} 4}\right)\end{array}$ & Length of last record in days \\
\hline & $\begin{array}{l}\text { Length of } \\
\text { previous } \\
\text { record }\left(x_{i 5}\right)\end{array}$ & Length of previous record in days \\
\hline \multirow[t]{3}{*}{$\frac{\Sigma}{8}$} & $\begin{array}{l}\text { Education } \\
\qquad\left(\mathrm{x}_{\mathrm{i}}\right)\end{array}$ & $\begin{array}{l}\text { Achieved level of education. Code: } 0 \text { - without education } \\
\text { or unfinished primary school, } 1 \text { - primary education (ZŠ), } \\
2 \text { - lower vocational education (NOV), } \\
3 \text { - secondary vocational education (SOV), } 4 \text { - complete } \\
\text { secondary education (USOV), } 5 \text { - higher vocational } \\
\text { education (VOV), } 6 \text { - 1st level of university education } \\
\text { (Bc.), } 7 \text { - } 2 \text { nd level of university education (Mgr./Ing.), 8- } \\
\text { 3rd level of university education (PhD.) }\end{array}$ \\
\hline & $\begin{array}{c}\text { ISCO code } \\
\text { (selected } \\
\text { codes used } \\
\text { separately) } \\
\left(x_{i 7}\right)\end{array}$ & $\begin{array}{l}\text { Previous employment of job seeker - code according } \\
\text { to the statistical classification of occupations. Code: } \\
1 \text { - Managers and legislators, } 2 \text { - specialists, } 3 \text { - Technical } \\
\text { and professional staff, } 4 \text { - Administrative staff, } 5 \text { - Service } \\
\text { and trade workers, } 6 \text { - Skilled workers in agriculture, } \\
\text { forestry and fishing, } 7 \text { - Skilled workers and craftsmen, } \\
8 \text { - Operators and fitters of machinery and equipment, } 9 \text { - } \\
\text { Auxiliary and unskilled workers. Variables used separately } \\
\text { as artificial variables (i.e., if ISCO = } 1 \text { in the group, } \\
\text { otherwise =0) }\end{array}$ \\
\hline & $\begin{array}{l}\text { Least } \\
\text { developed } \\
\text { regions }\left(\mathrm{x}_{\mathrm{i} 8}\right)\end{array}$ & $\begin{array}{l}\text { If the job seeker is from the Prešov, Košice and Banská } \\
\text { Bystrica self-governing regions }(7 ; 8 ; 6)=1 \text {, otherwise }=0\end{array}$ \\
\hline \multirow{3}{*}{$\frac{2}{2}$} & $\begin{array}{l}\text { Same } \\
\text { residence and } \\
\text { place of work } \\
\quad\left(\mathrm{x}_{\mathrm{ig}}\right)\end{array}$ & $\begin{array}{l}\text { If the job seeker has the same NUTS code of residence } \\
\text { and place of work, then the variable }=1 \text {, otherwise }=0\end{array}$ \\
\hline & $\begin{array}{l}\text { Year of } \\
\text { support } \\
\left(x_{i 10}\right)\end{array}$ & $\begin{array}{l}\text { Year in which the support was granted. The scope of the } \\
\text { monitored period is in the range } 2012 \text { - 2016. The code } \\
\text { assigned to each year is as follows: } 1 \text { - 2012, 2- 2013, } 3 \text { - } \\
2014,4-2015 \text { and } 5 \text { - } 2016 \text {. }\end{array}$ \\
\hline & $\begin{array}{l}\text { Amount of } \\
\text { support } \\
\left(x_{i 11}\right)\end{array}$ & $\begin{array}{l}\text { The total amount of financial support from the } \\
\text { instrument for self-employment allocated to the job } \\
\text { seeker (in euros) }\end{array}$ \\
\hline
\end{tabular}

Source: Author's own, 2021. 


\section{Results}

If we look at brief descriptive statistics, the largest share of the supported subjects are men. The average age is 37 years. $21 \%$ of the subjects had no previous employment, $44 \%$ are single and $46 \%$ of them have completed higher vocational education (23.4\% of the jobseekers were graduates of the $\mathrm{nd}$ level of higher education). Most often they come from the Žilina, Prešov and Banská Bystrica regions, two of which are among the least developed regions of Slovakia. Their average benefit amounted to $€ 3,570$, and they spent an average of 413 days on the register before becoming self-employed. The largest share of previous employment of the supported subjects is observed in the field of technicians and professionals; service and trade workers and craftsmen, processors, and repairers (according to the ISCO classification).

Overall, there is a very positive survival rate in the labor market (see Table 3) If we look exclusively at the models that examined only business survival, their values are halved. In the run, the values are slightly better, but still lag well behind labor market survival. An interesting finding is the fact that labor market survival in the least developed regions is always lower, except in the short-run, where the impact is up to 6 months, where survival exceeds that of the advanced region by 0.3 p.p. It is also interesting to note that while the short- and long-term differences during periods of economic growth are negligible, there is still a fairly significant decline in the long run when business is maintained. 
Table 3. Percentage of subsidized survival subjects in different conditions

\begin{tabular}{|c|c|c|c|c|c|}
\hline Models & Region & $\begin{array}{l}\text { Average } \\
\text { amount of the } \\
\text { contribution } \\
\text { to self- } \\
\text { employment } \\
\text { activity per } \\
\text { supported } \\
\text { subject } \\
\text { Up }\end{array}$ & $\begin{array}{l}\text { Total } \\
\text { number of } \\
\text { subjects } \\
\text { with } \\
\text { support } \\
\text { granted } \\
\\
3 \text { years }\end{array}$ & $\begin{array}{l}\% \text { Share of } \\
\text { subjects } \\
\text { that survival } \\
\text { on the labor } \\
\text { market } \\
\text { (total) }\end{array}$ & $\begin{array}{l}\text { \% Share of } \\
\text { subjects that } \\
\text { survival on } \\
\text { the labor } \\
\text { market (only } \\
\text { self-employed } \\
\text { subjects) }\end{array}$ \\
\hline 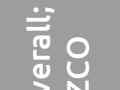 & $\begin{array}{l}\text { Developed } \\
\text { regions }\end{array}$ & $€ 3,035.13$ & 3,717 & $93.27 \%$ & $40.33 \%$ \\
\hline 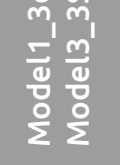 & $\begin{array}{l}\text { Least } \\
\text { developed } \\
\text { regions }\end{array}$ & $€ 3,936.01$ & 3,233 & $87.44 \%$ & $37.58 \%$ \\
\hline \multicolumn{6}{|c|}{ Up to 6 months } \\
\hline 产 & $\begin{array}{l}\text { Developed } \\
\text { regions }\end{array}$ & $€ 3,187.13$ & 5,409 & $91.78 \%$ & $56.09 \%$ \\
\hline 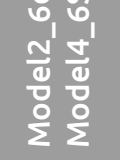 & $\begin{array}{l}\text { Least } \\
\text { developed } \\
\text { regions }\end{array}$ & $€ 4,032.21$ & 4,588 & $88.97 \%$ & $56.36 \%$ \\
\hline
\end{tabular}

Source: Author's own, 2021.

With this fact we can confirm that, despite the higher amount of contribution in the least developed regions, their subjects often have the lowest survival rates (except in the model4_6SZCO). It should be noted that the allowance is received by the unemployed, who may show a higher tendency to move back into unemployment if the subjects use this support as a temporary solution.

\subsection{Potential effects of selected factors on the probability of survival on the labor market}

We evaluate the potential effects of selected factors based on 4 models using the logistic regression method. The results of the regressions are shown in Tables 4 and 5, which show the values of the estimated logit of regression coefficients, their statistical significance and compare the values in two time bands, namely sustainability within 6 months and within 3 years.

The results show that in the Model1_3overall model, the statistically significant variables influencing the probability of survival in the labor market are mainly the subject's length of previous record, the subject's labor force participation in the least developed region and their previous employment (ISCO 
code). In other words, the survival of support in the broad sense is mainly affected by the subject's past history, with survival of support being shorter if the subject worked as a menial and unskilled worker in a region which is among the underdeveloped ones.

Looking purely at survival for subjects who have been self-employed for up to 3 years (Model3_3SZCO), the statistically significant variables are gender, age, previous employment, and length of previous record. Under a closer understanding of survival, we observe that men whose previous employment was in skilled trades and skilled manufacturing had a positive effect on the probability of survival as start-ups. As with the first model, the subject's past plays a role here. Age is an important factor in self-employment, which has a positive effect on long-term survival. It can be concluded that if the support is specifically targeted at the self-employed, survival is also more pronounced in terms of the age of the subject and their gender, with the place of employment taking a back seat.

Interestingly, when long-term survival is observed, the amount of support does not have a significant statistical effect on employment after the end of the support. The amount of support is likely to be offset by other benefits associated with employment in the region. 
Table 4. Result of logistic regression of factors influencing the survival on the labor market up to 3 years

\begin{tabular}{|c|c|c|}
\hline & Model1_3overall & Model3_3SZCO \\
\hline Male & $0.0146^{*}(2.442)$ & $1.41 * 10^{-7^{* * *}}(5.264)$ \\
\hline Single & $0.4053(0.832)$ & $0.3259(0.982)$ \\
\hline Age & $0.0284^{*}(-2.192)$ & $0.0003^{* * \star}(3.601)$ \\
\hline Length of last record & $0.0307 *(-2.161)$ & $0.1548(-1.423)$ \\
\hline Length of previous record & $2 * 10^{-16^{* * *}}(-8.424)$ & $9.95 * 10^{-7 * * *}(-4.893)$ \\
\hline $\begin{array}{l}\text { Education } \\
\text { Code } 1 \\
\text { Code } 2 \\
\text { Code } 3 \\
\text { Code } 4 \\
\text { Code } 5 \\
\text { Code } 6 \\
\text { Code } 7 \\
\text { Code } 8\end{array}$ & $\begin{array}{l}0.5930(0.534) \\
0.5603(0.582) \\
0.2809(1.078) \\
0.2033(1.272) \\
0.4573(0.743) \\
0.2622(1.121) \\
0.3115(1.012) \\
0.2619(1.122)\end{array}$ & $\begin{array}{c}0.8590(0.178) \\
0.8380(-0.204) \\
0.4235(0.800) \\
0.4589(0.741) \\
0.9767(-0.029) \\
0.6346(0.475) \\
0.7232(0.354) \\
0.9313(0.086)\end{array}$ \\
\hline Least developed regions & $2.57^{*} 10^{-5 * * *}(-4.208)$ & $0.0024^{* *}(-3.039)$ \\
\hline $\begin{array}{l}\text { ISCO category } 1 \\
\text { ISCO category } 2 \\
\text { ISCO category } 3 \\
\text { ISCO category } 4 \\
\text { ISCO category } 5 \\
\text { ISCO category } 6 \\
\text { ISCO category } 7 \\
\text { ISCO category } 8 \\
\text { ISCO category } 9\end{array}$ & $\begin{array}{r}0.2849(-1.069) \\
0.04302^{*}(-2.024) \\
0.2354(-1.456) \\
0.0108^{*}(-2.550) \\
0.0033^{* *}(-2.934) \\
0.1308(-1.511) \\
0.0300^{*}(-2.170) \\
0.0075^{* *}(-2.672) \\
0.0006^{* * *}(-3.422)\end{array}$ & $\begin{array}{r}0.0913 .(1.689) \\
0.1533(1.428) \\
0.847(1.568) \\
0.7677(-0.295) \\
0.6702(0.426) \\
0.003^{* *}(2.973) \\
1.22 * 10^{-7 * *}(\mathbf{5 . 2 9 0}) \\
0.9391(0.076) \\
0.5990(0.526)\end{array}$ \\
\hline Amount of support & $0.1107(-1.595)$ & $0.0117^{*}(2.520)$ \\
\hline $\begin{array}{l}\text { Year of support } \\
2012 \\
2013 \\
2014 \\
2015 \\
2016\end{array}$ & $\begin{array}{r}0.0032^{* *}(2.953) \\
0.0147^{*}(2.439) \\
0.6037(0.519) \\
0.9402(0.075) \\
0.9934(0.718)\end{array}$ & $\begin{array}{r}0.1730(1.363) \\
0.0128^{*}(-2.489) \\
0.0106^{*}(-2.555) \\
0.9344(-0.082) \\
0.9865(0.881)\end{array}$ \\
\hline Same region as place of work & $0.4898(-0.691)$ & $0.2345(1.189)$ \\
\hline C (constant) & $0.0006^{* * *}(3.437)$ & $0.0412^{*}(-2.042)$ \\
\hline Number of observed subjects & 6,950 & 6,950 \\
\hline
\end{tabular}

Note: The data above the parentheses are logit values, or the regression coefficient of logistic regression, data in parentheses are values of z-statistics and marks ${ }^{*} /{ }^{* *} /{ }^{* * *}$ mean statistical significance at the level of $10 / 5 / 1$ percent (. means significance level at the level of 0.1). Estimates are robust in terms of heteroskedasticity and autocorrelation.

Source: Author's own processing based on R data, 2021. 
Six-month labor market survival in the broader sense (employment, by agreement or self-employment) has a relatively larger number of factors that are statistically significantly more likely to affect survival - gender, previous employment, previous record or support. Retention after 6 months is negatively influenced by previous employment in the category of support and unskilled workers or the subject's past history. Conversely, the years of support (2012 2016) increase its likelihood of survival, mostly for male subjects. , labor

In the case of tracking the survival of self-employed-only subjects in the Model4_6SZCO models, the statistically significant variables influencing the probability of survival are mainly gender, the subject's previous registration, previous employment, the amount of support, and the fact that the area of their employment activity is in a least developed region. This model no longer follows the year of support being offered as a significant factor but is the only one that is positively affected by the amount of support. The amount of support was a statistically significant variable in the examined model Model4_6SZCO. This suggests that the amount of support may play a very important role in business retention, and not only in the employment of the supported person. 
Table 5. Result of logistic regression of factors influencing the survival on the labor market up to 6 months

\begin{tabular}{|c|c|c|}
\hline & Model2_6overall & Model4_6SzCO \\
\hline Male & $0.0002^{* * *}(3.751)$ & $4.37 * 10^{-9 * * *}(5.870)$ \\
\hline Single & $0.0473^{*}(1.984)$ & 0.0879. (1.707) \\
\hline Age & $0.1780(1.347)$ & $0.0040^{* *}(2.876)$ \\
\hline Length of last record & $0.1337(-1.500)$ & $0.2947(1.048)$ \\
\hline Length of previous record & $2 * 10^{-16^{* * *}}(-9.643)$ & $6.92 * 10^{-8 * * *}(-5.393)$ \\
\hline $\begin{array}{l}\text { Education } \\
\text { Code } 1 \\
\text { Code } 2 \\
\text { Code } 3 \\
\text { Code } 4 \\
\text { Code } 5 \\
\text { Code } 6 \\
\text { Code } 7 \\
\text { Code } 8\end{array}$ & $\begin{array}{l}0.3548(0.925) \\
0.5363(0.618) \\
0.1853(1.325) \\
0.1179(1.564) \\
0.8499(0.189) \\
0.1112(1.593) \\
0.1400(1.480) \\
0.2191(1.229)\end{array}$ & $\begin{array}{c}0.8905(-0.138) \\
0.9217(-0.098) \\
0.9015(0.124) \\
0.9682(-0.040) \\
0.3618(-0.912) \\
0.4984(-0.677) \\
0.6312(-0.480) \\
0.2240(-1.216)\end{array}$ \\
\hline Least developed regions & $0.0084^{* *}(-2.636)$ & $1.71 * 10^{-5 * * *}(-4.299)$ \\
\hline $\begin{array}{l}\text { Year of support } \\
2012 \\
2013 \\
2014 \\
2015 \\
2016\end{array}$ & $\begin{array}{r}5.65^{*} 10^{-5^{* * *}}(4.027) \\
1.70^{*} 10^{-14^{* * *}}(7.672) \\
2 * 10^{-16^{* * *}}(8.510) \\
2.62 * 10^{-13^{* * *}}(7.313) \\
2 * 10^{-14^{* * *}}(8.877)\end{array}$ & $\begin{array}{r}0.9680(0.040) \\
0.0129^{*}(2.487) \\
0.1235(1.540) \\
0.0068^{* *}(2.708) \\
0.0144^{*}(3.002)\end{array}$ \\
\hline $\begin{array}{l}\text { ISCO category } 1 \\
\text { ISCO category } 2 \\
\text { ISCO category } 3 \\
\text { ISCO category } 4 \\
\text { ISCO category } 5 \\
\text { ISCO category } 6 \\
\text { ISCO category } 7 \\
\text { ISCO category } 8 \\
\text { ISCO category } 9\end{array}$ & $\begin{array}{r}0.1046(2.314) \\
0.0750 .(2.949) \\
0.0021^{* *}(0.761) \\
0.0046^{* *}(1.977) \\
0.0500 .(0.376) \\
0.0180^{*}(2.184) \\
0.0012^{* *}(0.444) \\
0.1547(2.478) \\
2.13^{*} 10^{-5 * *}(-4.251)\end{array}$ & $\begin{array}{r}0.0543 .(1.925) \\
0.9762 .(1.657) \\
0.5006(-0.674) \\
0.0870 .(1.711) \\
0.9881 .(1.652) \\
0.2206(1.225) \\
2.99 * 10^{-10^{* * *}(6.299)} \\
0.8257(-0.220) \\
0.6701(0.426)\end{array}$ \\
\hline Amount of support & $0.8300(0.215)$ & $2 * 10^{-16^{* * *}}(8.284)$ \\
\hline Same region as place of work & $0.7221(0.356)$ & 0.0727. (1.795) \\
\hline C (constant) & $0.2212(1.223)$ & $0.0927 .(-1.681)$ \\
\hline $\begin{array}{c}\text { Number of observed } \\
\text { subjects }\end{array}$ & 9,997 & 9,997 \\
\hline
\end{tabular}

Note: The data above the parentheses are logit values, or the regression coefficient of logistic regression, data in parentheses are values of $z$-statistics and marks ${ }^{*} /{ }^{* *}{ }^{* * *}$ mean statistical significance at the level of $10 / 5 / 1$ percent (. means significance level at the level of 0.1 ). Estimates are robust in terms of heteroskedasticity and autocorrelation.

Source: Author's own processing based on R data, 2021. 


\section{Discussion}

In this section, we compare our results with the results of other studies that evaluated the survival of companies under different conditions. We focus on three groups of factors as defined in our theoretical background.

\subsection{Socio-demographic factors}

The study found a positive statistically significant effect of male gender on labor market survival. A study by Kuang-Ta Lo, Jiun-Nan Pan, Shi-Shu Peng (2020) also confirmed that men are more likely to survive in the labor market. However, there are standard reasons. Women are less tied to the labor market, have stronger family ties and are more inclined to work-life balance, which underlines this finding (Borik et al., 2015). The reason for greater sustainability in men is likely to maximize their income to support their families (Caliendo, 2016).

Whether survival was higher for single subjects has not been confirmed. We can be assumed that family support creates a better background in entrepreneurship. Some studies (Niittykangas and Tervo, 2005) even look for associations with previous family entrepreneurship, which may positively affect the survival of the current one (learning from parents, helping from a young age in entrepreneurship). Another factor related to marital status is the variable number of children studied by Caliendo and Kritikos (2010); Caliendo and Künn (2013); Millán and Congregado (2010) or Haapanen and Tervo (2009), unfortunately, we do not have such information.

Age and age structure is a very clearly anchored variable. It plays an important role in our analysis, exclusively for start-up survival. Studies (Holtz-Eakin, Joulfain and Rosen 1994; Parker, 2004) suggest that survival rates are higher for middle-aged than for younger or older self-employed people, as confirmed by our findings in the long-term study (average at 37 years of age). For example, in other studies such as Borika et al. (2015) age is also a statistically significant variable, and its average is 34 years. In a study by Ellen et al. (2021) it is about 46 years old; or Parker (2004) with an age limit of 40 years.

Although education does not play a significant role in our findings, a study by Pankaj and Marcus (2019) find that tradesmen who have higher financial capability based on education and experience are more prosperous and are able to survive longer in the labor market. Other studies (Borik et al., 2015; Parker, 2004; Niefert, 2010) have also found that higher levels of education have an input on self-employment as one of the positive survival factors. However, there аге also conflicting views and the impact of the educational level of subjects is uncertain according to the study by Baumgartner, Caliendo (2008). It is assumed that the higher the level of education attained, the lower the probability of choosing self-employment as more opportunities open up for subjects in the labor market. Although the overall impact is not recorded in our research, we will carefully attempt a possible interpretation of the impact. Unemployed people in our surveys usually have a lower formal education or a second level of higher education. Entities with lower education lack comprehensive prior 
knowledge that could increase the survival of their business, and in the case of university graduates, specific business experience. In the case of business from the state of unemployment, there may also be a push effect and a deadweight effect. Entities have a lower motivation to keep a business than paid employment entities (they have a strong motivation to be their own boss).

Previous employment as assessed by the ISCO classification plays a statistically significant variable in all models examined. In the case of models focusing exclusively on the self-employed, previous employment in the artisan and skilled producer sectors has a positive effect on survival (both short and long term). In contrast, examining the overall effects shows a negative statistical effect on the ancillary and unskilled workers, and their survival is lower. We assume that a key moment in survival support is the verification of the experience and business opportunities of the entities before starting a business (in our sample, $25 \%$ of the subjects have zero experience before support). As we mention in the methodology, there are no phases in Slovakia where we educate individuals before starting a business (we only observe the prerequisites for entrepreneurship in the form of a business plan). It may sound like we are looking at the first phase of support, but it is this beginning that can kick-start either a successful or unsuccessful end of support. We often find that the business plan is developed by a third party and so we do not know the real business knowledge. In other countries, it is often possible to combine self-employment support with education (Oberschachtsiekand Scioch, 2015; Wolff et al., 2016).

Similarly, the past history of the subject plays an important role. Long-term placement in the labor office had a negative effect in all models. The surveyed subjects spent on average 413 days as unemployed (approximately 13 months, which can be considered as long-term unemployed). Such subjects lose work habits and are less likely to enter the labor market after the end of the support period. This fact is not due to the set-up of the support, as the support can be drawn if the subject has been in the labor office for at least 3 months. It is more probable that it is a matter of usefulness. The choice of job selection varies with the usefulness that individual options offer. If it is more convenient for the entity to remain unemployed (sufficient unemployment benefits), it will remain unemployed. The problem arises later if the subject decides to go into business. The usefulness of unemployment benefits is reduced and the option of self-employment becomes more useful (e.g., changing regional conditions or behavioral aspects). The subject is likely to enter the labor market with limited access to information on business opportunities, which may lead to a lack of business ideas (most often no value-added goods). Despite the questionable profitability of the enterprise, the push effect forces them to operate, which ultimately has a negative impact on the survival of such an enterprise. A study by Haapanen and Tervo (2009), confirms that labor market entry will be more sustainable due to higher human capital, motivation and better awareness of business opportunities. The study further explains that starting a business in a new environment brings additional unexpected risks such as finding suppliers or customers or clients. 


\subsection{Regional labor market}

There was no significant effect on the likelihood that support would be more likely to survive if the place of work was equal to the region where the subject was located (either in the short or long term). In our research, we hypothesized, that in the Slovak labor market, subjects often move to where the work is and it is very important where the subject will be self-employed. To our surprise, this factor did not manifest itself. It can therefore be assumed that there are other contexts that address the issue. Probably, the factor under study is associated with the first phase of self-employment, not with the final phase - survival in the labor market. This factor loses strength during the support phase and in the sustainability phase it is more important whether the selected region has a solid basis for self-employment. In essence, it is more about the business conditions that exist for the unemployed at a given moment in time. Due to the unique indicator, we do not observe any impacts in other research.

If we look at a comparison of the impact of region, we see that people from the least developed region have lower survival rates, both in the labor market and in entrepreneurship. The only exception is the model measuring the short-term effects of staying in the labor market. This is probably related to the opportunities that the region provides for entrepreneurship and work. In general, a developed region provides more jobs and more demand for entrepreneurs, making it easier to work in times of economic growth (Huggins 2017), as our research confirms. Support policies seek to compensate for this shortfall with more support. In our case, this support is greater, but our results suggest that it cannot compensate for the negative environmental impact of the underdeveloped region. This may be due both to the relatively small difference in amount of this support across regions, but also to the fact that a large proportion of entrepreneurs may be indispensable entrepreneurs (Caliendo and Kuhn, 2013). If we look at the comparison of the impact of the region, we see that people from the least developed region have lower survival rates, both in the labor market and in entrepreneurship. The only exception is the model measuring the short-term effects of staying in the labor market. This is probably related to the opportunities that the region provides for entrepreneurship and work. In general, a developed region provides more jobs and more demand for entrepreneurs, making it easier to work in times of economic growth (Huggins 2017), as our research confirms. Support policies seek to compensate for this shortfall with more support. In our case, this support is greater, but according to the results, it cannot compensate for the negative environmental impact of the underdeveloped region. This may be due to the relatively small variation in this support across regions and the fact that a large proportion of entrepreneurs may necessarily be entrepreneurs (Caliendo and Kuhn, 2013) who would rather work as employees and end up going out of business to find a job when the opportunity arises. These opportunities are more common in more economically developed regions.

According to Caliendo, Künn (2013), the impact of the business environment is also due to weaker initial investment by those who entered self-employment 
due to unemployment. The least developed region factor has a negative impact on all subjects in the long run, not only on self-employed entrepreneurs. This suggests that other subjects who are either employed or contracted in the market are affected by market conditions much later. That company survival is lower in disadvantaged areas is confirmed by the findings of the Tervo study (2006). The study further suggests that the worse the conditions are in disadvantaged economic areas, the higher the likelihood of self-employment (opportunity cost).

\subsection{Economic factors}

Based on data for Slovakia as a whole, the level of support under the allowance has a short-term positive effect on employment after the end of the support period only for the self-employed. The amount of funds is logically more important for those who remain in business as employed after the end of the support. The fact that this effect is mainly short-term can be explained by its importance for business start-ups. In the long run, the sufficiency of financial resources substitutes for other factors that sustain the business.

The cost-effectiveness of support entails significant economic risks (wasted resources, uneven distribution, demanding conditions), as confirmed by Danson, Galloway, Sherif (2021). A study by Cueto and Mato (2009) determined self-employment survival rates to be around $93 \%$ after 2 years and $76 \%$ after 5 years. After 3 years, our findings are at about $40 \%$ for the self-employed, which is considerably less (short-term sustainability is somewhat more pronounced in our setting, at about $56 \%$ ). Values when employed reach sustainability above $85 \%$. The significant differences between countries can be justified in two ways. The first reason is the need to distinguish between survival in employment and in self-employment. As our research shows, survival on the labor market behaves very differently depending on the location of the subject based on support. The second reason is the overall duration of the assistance. While in Slovakia we analyze survival up to 3 years of 3-year support, in other countries the time is much shorter, for example, in Sweden it is only for a period of 6 months (replicating the unemployment benefit) and the benefit is for everyone. In Germany, according to a study by Caliendo, Künn (2013), support is paid during the first 6 months of self-employment and is conditional on eligibility for unemployment benefits. In addition, there is another instrument in Germany that is paid out over a 3-year period and covers the long-term unemployed and individuals with limited income and labor market experience. Niefert's (2010) study reveals the fact that subjects have to prove their personal and professional competence, which would solve a number of teething problems when starting a business (although it would prolong the administrative burden to some extent).

The last factor examined was the year of support. The factor analyzed points rather to the macroeconomic context of the support, where it is assumed that the first years examined achieved more favorable conditions for starting a business, as Slovakia has moved out of unfavorable conditions in the unemployment rate (in 2012 the unemployment rate was 14.4\%, in 2017 it was only 5.94\%). As other studies show (Tervo, 2006), unfavorable adverse market 
conditions mean that the subject is likely to choose self-employment rather over paid work (few opportunities, low wages). Our results confirm this, as we register a higher number of subjects with this support in the first two years, with the number declining afterwards. From the results of the analyses, we also observe a short-term positive impact on overall survival on the labor market in all years examined, which only partially confirms our assumption.

\section{Conclusion}

The aim of the paper was to examine the survival of start-ups from the state of unemployment in Slovakia. Survival rates and factors influencing survival were examined both in the short-term (up to 6 months after the end of support) and long-term (up to 3 years after the end of support). They were also evaluated in terms of the supported person's retention in the labor market and the survival of their business. It can be concluded that the support is fit for purpose when considered as an active labor market policy to integrate individuals into the labor market. In a period of economic growth, more than $88 \%$ remained in employment in the long term. However, only half of the supported unemployed remained in business. It suggests that this measure is not very useful as a policy to promote entrepreneurship.

The results for Slovakia in the period 2012-2016 show that survival in all 4 models examined is negatively affected by the subject's past history (how many times and how often was the subject in the labor office). The labor market sustainability models identify lower survival rates for ancillary and unskilled workers, suggesting that these workers have only used the support as a necessity and are unlikely to have the skills to run a successful business. Due to economic growth and abundant job offers, they have taken advantage of them and become employees, which "fits" as better than owning their own businesses. Business survival patterns show higher survival rates for craft and skilled workers, suggesting that self-employment requires a certain level of education and more significant practical experience in the field. In less developed regions, this policy has led to lower sustainability in both the labor market, and entrepreneurial activities in the long run.. However, the differences were smaller for business survival, suggesting that this economic policy could focus more on these regions.

We can conclude that the support is fit for purpose when considered as an active labor market policy to integrate individuals into the labor market. However, in the conditions of Slovakia, this leads to much less sustainability of entrepreneurial activities than is the case in other countries.

We note that the study is constructed in terms of macroeconomic factors in times of economic boom, which can significantly affect the behavior of individuals and the policy settings as such. If we look at the current situation (caused by the COVID-19 pandemic), which points more to the decline in economic development and the labor market, other factors are likely to play a role. What impact this will have and what new factors will potentially influence support could be the subject of further research. 


\section{References}

Act no. 5/2004 Coll. Act on Employment Services and on Amendments to Certain Acts.

Baumgartner, H. J., and Caliendo, M. (2008). Turning unemployment into selfemployment: effectiveness of two start-up programmes. Oxford Bulletin of Economics and Statistics, 70(3), pp. 347-373. https://doi.org/10.1111/j.14680084.2008.00505.x.

Bořik, V., and Caban, M. (2013). Pilotné hodnotenie dopadov vybraných opatrení aktívnej politiky trhu práce. At <http://www.evaluacia.sk/wp-content/ uploads/2012/12/vborik.pdf>, accessed 15 September 2021.

Bořik, V. et al. (2015). The Net Effects of Graduate Work Experience and the Promotion of Self-employment: Technical Report. At <https://www. employment.gov.sk/files/slovensky/esf/op-zasi/technical-evaluation-report_ final5edit.pdf>, accessed 7 August 2021.

Caliendo, M., and Kritikos, A. S. (2010). Start-ups by the unemployed: Characteristics, survival and direct employment effects. Small Business Economics, 35(1), pp. 71-92. https://doi.org/10.1007/s11187-009-9208-4

Caliendo, M., and Künn, S. (2013). Regional Effect Heterogeneity of Start-Up Subsidies for the Unemployed. IZA Discussion Papers, 7460, pp. 1108-1134. http://ftp.iza.org/dp7460.pdf.

Caliendo, M., Künn, S., and Weißenberger, M. (2016). Personality Traits and the Evaluation of Start-Up Subsidies. European Economic Review, 86, pp. 87-108. https://doi.org/10.1016/j.euroecorev.2015.11.008.

Caliendo, M., and Schmidl, R. (2016). Youth unemployment and active labor market policies in Europe. IZA Journal of Labor Policy, 5(1). https://doi. org/10.1186/s40173-016-0057-x.

Cueto, B., and Mato, J. (2009). A nonexperimental evaluation of training programmes: regional evidence for Spain. The Annals of Regional Science, 43, pp. 415-433. https://doi.org/10.1007/s00168-008-0214-2.

Cueto B., Mayor M., Suárez P. (2015). Entrepreneurship and unemployment in Spain: a regional analysis. Applied Economics Letters, 22, pp. 1230-1235. http://dx.doi.org/10.1080/13504851.2015.1021450.

Duhautois, R., Redor D., and Desiage L. (2015). Long Term Effect of Public Subsidies on Start-up Survival and Economic Performance: An Empirical Study with French Data. Revue d'économie industrielle, 149, pp. 11-41. https://doi. org/10.4000/rei.6063.

Dvouletý, O., and Hora, O. (2020). Analýza dopadů programu podpory podnikání pro nezaměstnané v České republice. Politická ekonomie, 68 (2), pp. 142167. https://doi.org/10.18267/j.polek.1267.

Ellen, E. et al. (2021). Employment trajectories until midlife associate with early social role investments and current work-related well-being. Advances in Life Course Research, 47: 100391. https://doi.org/10.1016/j.alcr.2020.100391

Eurostat: LMP expenditure by type of action - summary tables. (2021). After Using our research data. At <https://webgate.ec.europa.eu/empl/redisstat/ databrowser/view/LMP_EXPSUMM/default/table>, accessed 17 June 2021.

Haapanen, M., and Tervo, H. (2009). Self-employment duration in urban and rural locations. Applied Economics, 41(19), pp. 2449-2461. https://doi. org/10.1080/00036840802360278.

Huggins, R., Prokop, D. and Thompson, P. (2017). Entrepreneurship and the determinants of firm survival within regions: human capital, growth 
motivation and locational conditions. Entrepreneurship \& Regional Development, 29(3-4), pp. 357-389. At <https://doi.org/10.1080/08985626.2 016.1271830>, accessed 26 June 2021.

Holtz-Eakin, D., Joulfain, D. and Rosen, H. S. (1994). Sticking it Out: Entrepreneurial Survival and Liquidity Constraints. Journal of Political Economy, 102, pp. 53-75. At <http://www.jstor.org/stable/2138793>, accessed 2 July 2021.

Kuang-Ta Lo, Jiun-Nan Pan and Shi-Shu Peng. (2020). The role of gender and its potential channels to affect self-employment in Taiwan. Economic Modelling, 89, pp. 601-610. https://doi.org/10.1016/j.econmod.2020.02.030

LMP methodology: Labor market policy Statistics. (2018). After Using our research data. At <https://ec.europa.eu/social/main.jsp?catld=738\&langld=en \&publd=8126\&furtherPubs=yes>, accessed 18 June 2021.

Meager, M., Bates, P. and Cowling, M. (2003). An evaluation of business startup support for young people. National Institute Economic Review, 186, pp. 59-72. https://doi.org/10.1177/002795010300100111

Danson, M., Galloway L., and Sherif, M. (2021). From unemployment to selfemployment: Can enterprise policy intensify the risks of poverty? Critical Perspectives on Accounting, 75, 102164. https://doi.org/10.1016/j. сра.2020.102164

Millán M. J., and Congregado E. (2010). Determinants of self-employment survival in Europe. Small Business Economics, 38, pp. 231-258. https://doi. org/10.1007/s11187-010-9260-0.

Niefert, M. (2010). Characteristics and Determinants of Start-ups from Unemployment: Evidence from German Micro Data. Journal of Small Business and Entrepreneurship, 23(3), pp. 409-429. https://doi.org/10.1080/08276331 .2010.10593493.

Niittykangas, H. and Tervo, H. (2005). Spatial Variations in Intergenerational Transmission of Self-Employment. Regional Studies, 39, pp. 319-332. https:// doi.org/10.1080/00343400500087166

Oberschachtsiek, D. and Scioch P. (2015). The outcome of coaching and training for self-employment: A statistical evaluation of outside assistance support programs for unemployed business founders in Germany. Journal for Labor Market Research, 48(1), pp. 1-25. https://doi.org/10.1007/s12651-014-0161-6.

Patel, P. C., and Wolfe, M. T. (2019). Money might not make you happy, but can happiness make you money? The value of leveraging subjective well-being to enhance financial well-being in self-employment. Journal of Business Venturing Insights, 12: e00134. https://doi.org/10.1016/j.jbvi.2019.e00134

Parker, S. C. (2004). The economics of self-employment and entrepreneurship. Cambridge University Press. https://doi.org/10.1017/CBO9780511493430.

R Core Team. (2020). R: A language and environment for statistical computing. R Foundation for Statistical Computing. At <https://www.R-project.org/>.

Tervo, H. (2006). Regional Unemployment, Self-employment and Family Background. Applied Economics, 38, pp. 1055-1062. https://doi. org/10.1080/00036840500400053.

Wolff, J., Nivorozhkin, A., and Bernhard, S. (2016). You can go your own way! The long-term effectiveness of a self-employment programme for welfare recipients in Germany. International Journal of Social Welfare, 25(2), pp. 136-148. https://doi.org/10.1111/ijsw.12176.

Wright, R. E. 1995. Logistic regression. American Psychological Association: 217-244. 
Appendices

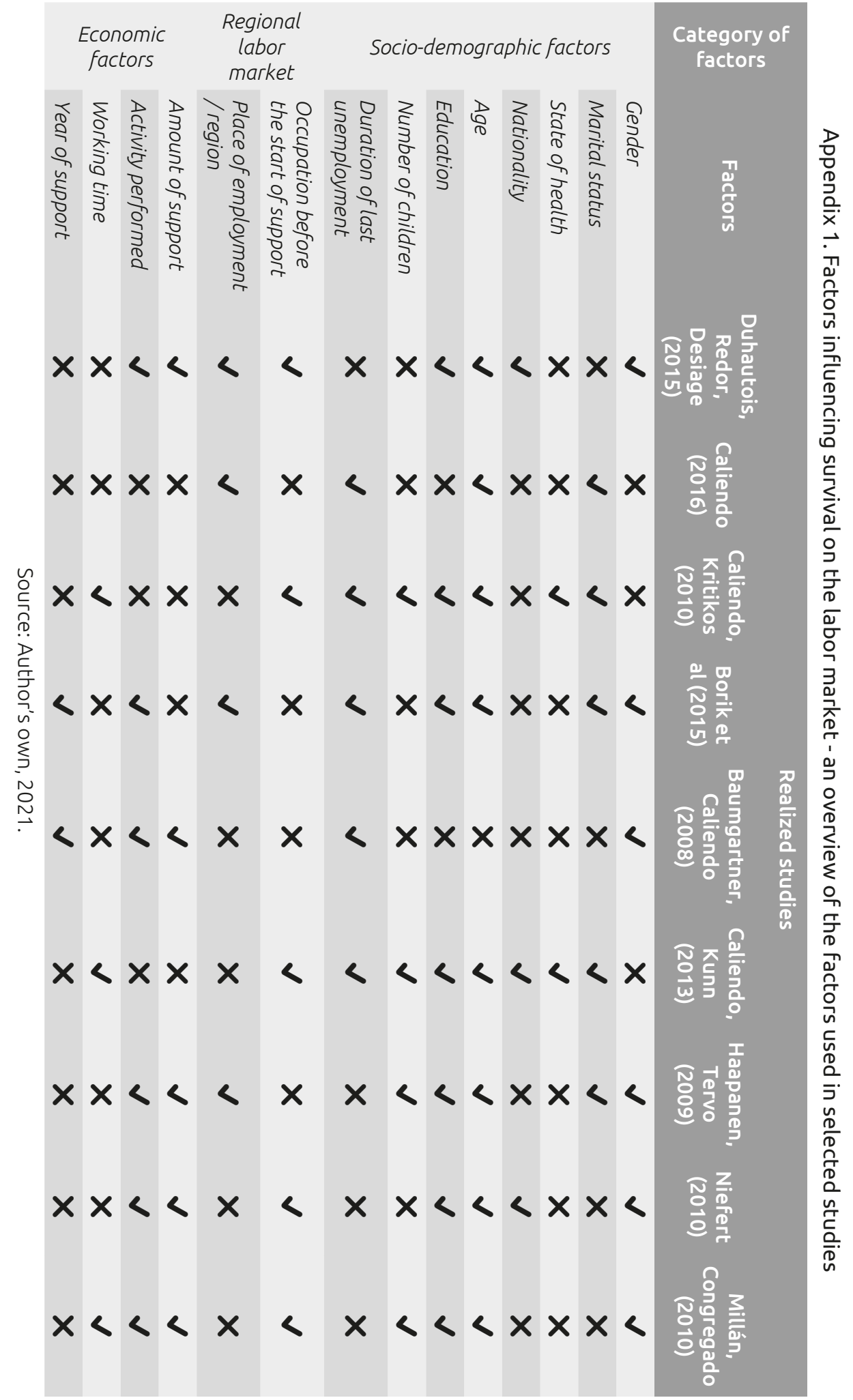

